\title{
ANAEROBIC POWER AND REPETITIVE MUSCLE WORK CAPACITY OF OLDER ELITE AND DEVELOPING YOUNG BASKETBALL PLAYERS
}

\author{
Rūtenis Paulauskas, Rūta Dadelienė, Rasa Paulauskienė, Juozas Skernevičius \\ Lithuanian University of Educational Sciences, Vilnius, Lithuania
}

\begin{abstract}
Research background and hypothesis. Players need to repeat performance of highly intensive work for a particular time combining it with rest intervals. The muscle power and anaerobic repetitive muscle work capacity of elite basketball players is higher than those in young athletes.

Research aim was to investigate anaerobic power and repetitive muscle work capacity of older elite $(n=13)$ and young basketball players $(\mathrm{n}=12)$ and to carry out comparative analysis of indicators in these groups.

Research methods. During competition period, laboratory $5 \times 6 \mathrm{~s}$ repeated effort test with rest intervals of $24 \mathrm{~s}$ was employed. The average indicator of power during each work interval was provided and fatigue index was calculated. Three minutes after the physical load, the concentration of lactate in the blood was measured.

Research results. A statistically significant difference was observed for absolute muscle power of elite and young basketball players in the first sprint $(\mathrm{p}<0.004)$ The research on relative indicators for one kilogram of the body mass showed that the power of elite $\left(13.06 \mathrm{~W} \cdot \mathrm{kg}^{-1}\right)$ and young players $\left(11.74 \mathrm{~W} \cdot \mathrm{kg}^{-1}\right)$ did not differ statistically $(\mathrm{p}<0.09)$. The fatigue index investigated in both groups did not differ $(\mathrm{p}<0.77)$.

Discussion and conclusions. The research revealed that relative indicators of muscle power of elite basketball players did not significant differ from those of young athletes. The same anaerobic repetitive muscle work capacity was observed in both groups.

It was established that the concentration of lactate in the blood increased after physical load more than to $9 \mathrm{~mol} \cdot \mathrm{l}^{-1}$ and did not differ in the two groups. This means that working for 6 seconds at maximum strength and relaxing 4 times longer, repeating this work five times, $\mathrm{PCr}$ is not enough for ATP resynthesis and, therefore, anaerobic glycolic reactions are activated.
\end{abstract}

Keywords: fatigue, lactate, recovery, muscles.

\section{INTRODUCTION}

$\mathrm{D}$ uring the basketball game the duration of work may vary from a momentary throw or a pass to repetitive work that lasts for several hours. A player is referred to as possessing high endurance if he/she is able to demonstrate technical-tactical abilities and skills as well as physical possibilities during the match (Bompa, Haff, 2009). Muscular endurance is the capacity to sustain a static contraction or repeated muscle contractions (Wilmore et al., 2008)

Taking into account the content of basketball players' work, that is, duration and intensity of play actions (Trninic et al., 2000), proportions of breaks with work, emotional effect on the organism (Karipidis et al., 2001), the dominant role is assumed by repetitive work power and specific capacity (Hargreaves et al., 1992). This embraces an ability to cope with fatigue striving for achievement of the best results under specific conditions of play (Mendes, Janeira, 2001).

Players need to repeat performance of highly intensive work for a particular time combining them with rest intervals. This is predetermined by the rules of the game: size of basketball court, 
duration of attack, duration of match, timeouts and other breaks during the play (Krause et al., 2008). The biggest role is played by the ability of the player's organism to recover fast (Buceta, 2000; Wissel, 2004). The situations, when players are given different time to play are characteristic of basketball (Carter et al., 2005). Such indicators as speed of recovery of energetic substances in muscles, functional power of circulatory and respiratory systems are among the most important indicators of basketball players' capacity (Foster et al., 1996; Kraemer, 2000). We have established that while playing basketball energy is generated resynthesizing ATP from $\mathrm{PCr}$ and from mixed energy source $\mathrm{PCr}$ - glycogen, without oxygen, i. e. working very intensively for a short period of time (Paulauskas et al., 2010). However, the repetitive work capacity of players has not been extensively analyzed all over the world. Being aware of repetitive work power and endurance, we could evaluate and more efficiently develop and train players.

The aim of our study was to investigate repetitive muscle work power and specific capacity of elite and young basketball players and to carry out comparative analysis of indicators in these groups.

\section{RESEARCH METHODS}

Participants. Elite basketball players $(\mathrm{n}=13)$, who regularly trained 8 times per week and played in competitions of Lithuanian Basketball League (LBL) and Baltic Basketball League, were researched. Their age was $25.6 \pm 0.6$ years, height $195.9 \pm 1.7 \mathrm{~cm}$ and body mass $-94.7 \pm 4.3 \mathrm{~kg}$.

The sample also included young basketball players $(n=12)$, who regularly trained 4 times a week and played in school learners' competitions. Their age was $14.1 \pm 0.2$ years, height $-183.7 \pm 3.4$ $\mathrm{cm}$ and body mass $-69.5 \pm 2.2 \mathrm{~kg}$. The participants and, if necessary, their guardians were informed about the aims and procedures of the study before providing their written informed consent. The study was approved by Lithuanian Bioethics Committee, according to Resolution \#30/2008.

Procedures. During the competition period, laboratory $5 \times 6 \mathrm{~s}$ repeated effort test with rest intervals of $24 \mathrm{~s}$ was employed (Ward, 1991; Fitszimon et al., 1993). The veloergometer "Monark Ergomedic 894 Ea" was used for this test. The average muscle power during each work interval was provided in watts (W) and fatigue index (FI) was calculated applying the formula:

$$
\text { FI }(\%)=100-(\mathrm{P} 5 / \mathrm{P} 1 \times 100)
$$

Three minutes after the physical load, the concentrate of lactate in the blood was measured applying the blood lactate test meter "Lactate Pro".

Statistical analysis. All data were analyzed using SPSS for Windows v. 14.0. The results were processed applying methods of descriptive statistics: Mean values were calculated, dispersion was evaluated calculating standard deviation of sample (s) and according to coefficient of variation $(\mathrm{CV})$, providing parameters (Min and Max) of dispersion area. Dispersion analysis (ANOVA) was used to compare the two groups. Statistical significance was set at $\mathrm{p}<0.05$.

\section{RESEARCH RESULTS}

Average muscle power was the highest during the first sprint and then gradually decreased in both groups (Figure 1). A statistically significant difference was observed for absolute muscle power of elite and young basketball players in the first sprint $(\mathrm{p}<0.004)$ (Table 1). Significant dispersion of indicators was characteristic of both groups: coefficient of variation (CV) exceeded by $20 \%$. The research on relative indicators for one kilogram of the body mass showed that the power of elite $\left(13.06 \mathrm{~W} \cdot \mathrm{kg}^{-1}\right)$ and young players $\left(11.74 \mathrm{~W} \cdot \mathrm{kg}^{-1}\right) \mathrm{did}$ not differ statistically $(\mathrm{p}<0.09)$. The dispersion of indicators of young basketball players totalled $10.5 \%$, whereas it amounted to $18.2 \%$ in the group of elite basketball players.

The most significant difference in muscle power was recorded in both groups during the second work interval. The absolute indicators of higher performance basketball players were higher by $436.2 \mathrm{~W}(\mathrm{p}<0.0001)$, the same tendency was observed in the values of relative indicators, which were by $1.7 \mathrm{~W} \cdot \mathrm{kg}^{-1}$ bigger in the group of elite players $(\mathrm{p}<0.02)$.

Power indicators decreased at similar rate in both groups during the third, fourth and fifth work intervals. The absolute muscle power of elite basketball players remained statistically higher during these work intervals, whereas relative power did not differ. Dispersion of power indicators around the mean changed insignificantly in all the intervals of work.

Table 2 presents the values of muscle capacity. The change observed between the first and second 
work intervals showed anaerobic ATP-PCr muscle power capacity. The difference in the relative muscle power of elite basketball players totalled by $0.32 \mathrm{~W} \cdot \mathrm{kg}^{-1}$ and that of young players equalled to $0.75 \mathrm{~W} \cdot \mathrm{kg}^{-1}$. Significantly smaller fatigue index $(p<0.03)$ was identified in the group of elite players compared to young players, which revealed greater anaerobic ATP-PCr muscle power capacity.

Evaluating repetitive work capacity, the difference between the first and fifth work interval was calculated. The absolute muscle power of elite basketball players totaled $128.2 \mathrm{~W}$ and that of young athletes was lower by $76.9 \mathrm{~W}$. The difference between the two groups was statistically significant $(p<0.05)$. The fatigue index investigated in both groups did not differ.

After the physical load, the lactate concentration in the blood was measured, which was $9.1 \mathrm{mmol} \cdot \mathrm{l}^{-1}$ in the group of young basketball players, whereas the lactate concentration in the blood of professional basketball players equalled to $9.5 \mathrm{mmol} \cdot \mathrm{l}^{-1}$. No statistically significant difference was recorded in both groups. As it can be seen from the results, very large dispersion about the mean $\mathrm{CV}=41.4 \%$ was observed in the group of young players. Dispersion of these indicators in the group of professionals was smaller compared to the other group but it still remained large $(\mathrm{CV}=25.5 \%)$.
Figure 1. Change in absolute muscle power (W) of elite and young basketball players performing $5 \times 6 \mathrm{~s}$ repeated effort test

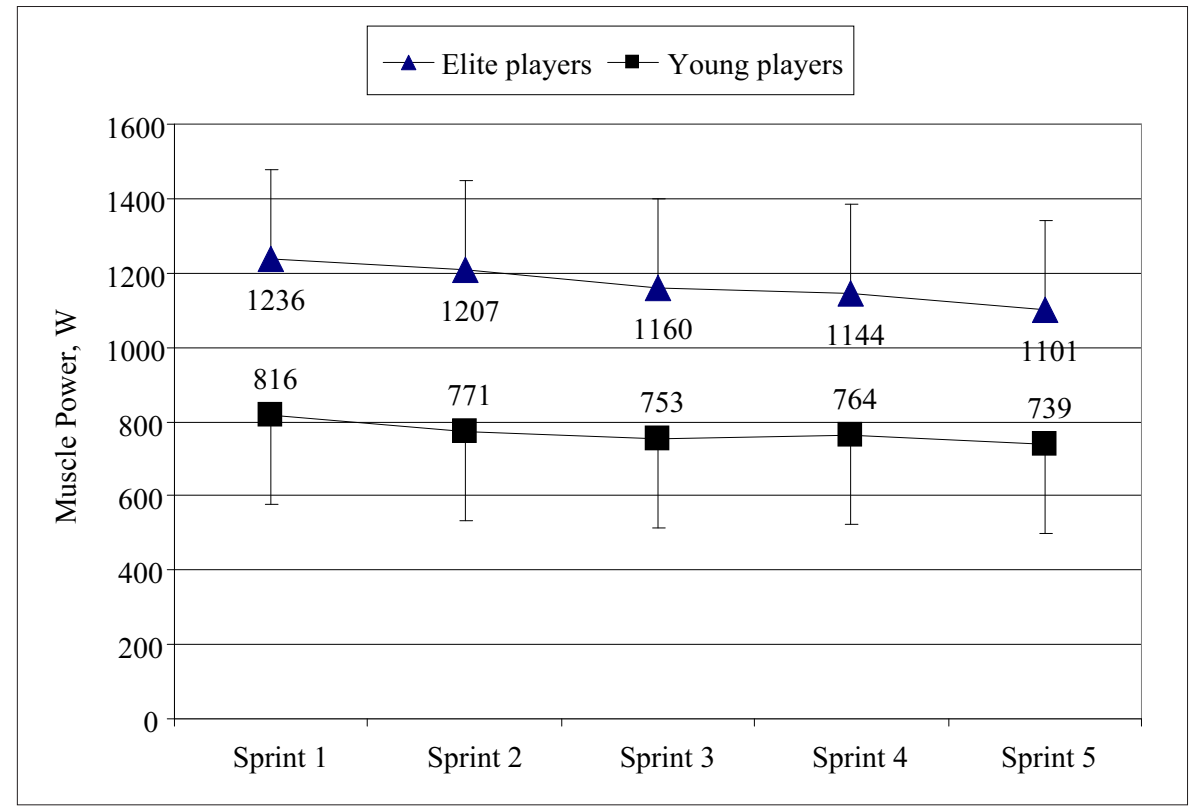

Table 1. Muscle power of elite and young basketball players performing $5 \times 6 \mathrm{~s}$ repeated effort test

\begin{tabular}{|c|c|c|c|c|c|c|c|c|c|c|c|}
\hline \multirow{2}{*}{ Sample } & & \multicolumn{2}{|c|}{ Sprint 1} & \multicolumn{2}{|c|}{ Sprint 2} & \multicolumn{2}{|c|}{ Sprint 3} & \multicolumn{2}{|c|}{ Sprint 4} & \multicolumn{2}{|c|}{ Sprint 5} \\
\hline & & $\mathbf{W}$ & $\mathbf{W} \cdot \mathbf{k g}^{-1}$ & $\mathbf{W}$ & $\mathbf{W} \cdot \mathbf{k g}^{-1}$ & W & $\mathbf{W} \cdot \mathbf{k g}^{-1}$ & $\mathbf{W}$ & $\mathbf{W} \cdot \mathbf{k g}^{-1}$ & $\mathbf{W}$ & $\mathbf{W} \cdot \mathbf{k g}^{-1}$ \\
\hline \multirow{5}{*}{$\begin{array}{c}\text { Elite } \\
\text { basketball } \\
\text { players }\end{array}$} & Mean & 1235.8 & 13.06 & 1207.08 & 12.78 & 1160 & 12.28 & 1144.2 & 12.11 & 1101.2 & 11.65 \\
\hline & $\mathrm{S}$ & 289.08 & 2.37 & 264.24 & 2.22 & 272.77 & 2.33 & 265.58 & 2.21 & 249.15 & 2.04 \\
\hline & CV\% & 23.39 & 18.17 & 21.89 & 17.39 & 23.51 & 18.97 & 23.21 & 18.28 & 22.62 & 17.52 \\
\hline & Min & 973 & 9.67 & 966 & 9.62 & 890 & 8.77 & 883.00 & 8.97 & 842.00 & 8.87 \\
\hline & Max & 1909 & 16.7 & 1809 & 15.87 & 1846 & 16.20 & 1848 & 16.2 & 1749.0 & 15.34 \\
\hline \multirow{5}{*}{$\begin{array}{c}\text { Young } \\
\text { basketball } \\
\text { players }\end{array}$} & Mean & 816.00 & 11.74 & 770.83 & 11.09 & 752.75 & 10.81 & 763.75 & 10.94 & 739.08 & 10.59 \\
\hline & $\mathrm{S}$ & 210.61 & 1.24 & 203.98 & 0.99 & 211.04 & 1.13 & 215.50 & 0.88 & 216.29 & 1.13 \\
\hline & CV\% & 25.81 & 10.52 & 26.46 & 8.91 & 28.04 & 10.43 & 28.22 & 8.07 & 29.26 & 10.66 \\
\hline & Min & 598.00 & 9.83 & 617.00 & 9.57 & 584.00 & 9.17 & 579.00 & 9.57 & 558.00 & 9.07 \\
\hline & Max & 1392 & 14.1 & 1370 & 13.15 & 1364 & 12.66 & 1388 & 12.7 & 1363 & 12.6 \\
\hline P-value & & $<0.004$ & 0.098 & $<0.0001$ & $<0.024$ & $<0.004$ & 0.061 & $<0.0007$ & 0.099 & $<0.008$ & 0.12 \\
\hline
\end{tabular}

Note: CV - coefficient of variation. 
Table 2. Muscle power decrement of elite basketball players and young players between work interval 1 and 2 as well as between 1 and 5 , as well as concentration of lactate in the blood

\begin{tabular}{|c|c|c|c|c|c|c|c|c|}
\hline \multirow{2}{*}{ Sample } & & \multicolumn{3}{|c|}{ Sprints 1-2 } & \multicolumn{3}{|c|}{ Sprints 1-5 } & \multirow{2}{*}{$\begin{array}{c}\text { La } \\
\mathrm{mmol}^{-1} \mathrm{l}^{-1}\end{array}$} \\
\hline & & $\mathbf{W}$ & $\mathbf{W} \cdot \mathbf{k g}^{-1}$ & FI (\%) & $\mathbf{W}$ & $\mathbf{W} \cdot \mathbf{k g}^{-1}$ & FI (\%) & \\
\hline \multirow{5}{*}{$\begin{array}{c}\text { Elite } \\
\text { basketball } \\
\text { players }\end{array}$} & Mean & 28.77 & 0.32 & 2.05 & 128.23 & 1.35 & 10.11 & 9.48 \\
\hline & S & 31.29 & 0.27 & 1.79 & 71.80 & 0.70 & 4.42 & 2.42 \\
\hline & $\mathrm{CV} \%$ & 108.75 & 85.69 & 87.23 & 55.99 & 52.33 & 43.77 & 25.52 \\
\hline & Min & 3.00 & 0.04 & 0.36 & 38.00 & 0.38 & 3.85 & 5.40 \\
\hline & Max & 100.00 & 0.87 & 6.24 & 287.00 & 2.96 & 18.77 & 13.30 \\
\hline \multirow{5}{*}{$\begin{array}{c}\text { Young } \\
\text { basketball } \\
\text { players }\end{array}$} & Mean & 51.67 & 0.76 & 6.32 & 76.92 & 1.15 & 9.74 & 9.12 \\
\hline & S & 35.91 & 0.51 & 4.02 & 38.08 & 0.57 & 4.65 & 3.77 \\
\hline & $\mathrm{CV} \%$ & 69.51 & 67.63 & 63.62 & 49.51 & 49.79 & 47.77 & 41.40 \\
\hline & Min & 17.00 & 0.19 & 1.58 & 29.00 & 0.26 & 2.08 & 5.60 \\
\hline & Max & 128.00 & 1.83 & 15.15 & 143.00 & 1.92 & 17.46 & 15.20 \\
\hline P-value & & $<0.143$ & $<0.003$ & $<0.031$ & $<0.038$ & 0.505 & 0.990 & 0.772 \\
\hline
\end{tabular}

Note: $\mathrm{CV}$ - coefficient of variation.

\section{DISCUSSION}

The study shows that absolute indicators of muscle power were higher in the group of elite athletes compared to the same indicators of young players (Figure 1). However, differences in relative muscle power were observed only in the second work interval. This means that 14 -yearold players equalled to elite athletes in relative power of short muscle work. It can be stated that the average relative anaerobic alactic muscle power of professionally trained athletes is not sufficient. However, both relative and absolute anaerobic alactic muscle powers are significant because in play situations an athlete has to overcome not only the power of their own body gravity, but also to cope with a personal contact with an opponent.

L. Ellis et al., (2000) point out that in game situations high average indicator is of utmost importance during all the five work intervals. $\mathrm{He}$ stated that the average relative muscle power of elite ice hockey players totaled to $13.2 \mathrm{~W} \cdot \mathrm{kg}^{-1}$, whereas that of the researched elite basketball players equaled to $12.4 \mathrm{~W} \cdot \mathrm{kg}^{-1}$, and the average relative muscle power in the group of young basketball players totalled to $11.1 \mathrm{~W} \cdot \mathrm{kg}^{-1}$ (Figure 2).

Applying this test it was necessary to evaluate the change in the power of short muscle work under conditions of short recovery time. A decrease in work power is expressed through fatigue index (FI), where lower value refer to better endurance of muscle power. Table 2 contains the fatigue index of anaerobic alactic muscle power, which is particularly important in basketball and other sports games. It can be seen that young players fall behind adult ones. P. Astrand and K. Rodahl (1986), J. Wilmore et al. (2008) point out that the prevailing duration of anaerobic alactic energy production reactions ranges from 6 to $10 \mathrm{~s}$. Working at maximum intensity for such a period, phosphocreatine (PCr) resynthesizes ATP enough. According to the authors mentioned above, recovery depends on a big number of factors but the main processes occur within 1.5-3 min. During the conducted research, the rest period between work intervals amounted to $24 \mathrm{~s}$. Therefore, the main factor predetermining better capacity of anaerobic alactic muscle capacity could be a bigger reserve of $\mathrm{PCr}$ accumulated in muscles as well as higher activity of creatine-kinase (Kraemer, Ratamess, 2005).

The fatigue index was the same in both groups. A. Stapf (2000) suggests that good fatigue index of repetitive work capacity of elite Australian basketball players equaled to $5 \%$. The FI of elite basketball players in the research sample was $10.1 \%$, similar to that of young players $(9.7 \%)$.

Fatigue index is not correlated with a large number of indicators of physical development and physical fitness (Fitszimons et al., 1993). Evaluating the effect of repetitive work on the activity of glycolytic reactions in muscles, the concentration of lactate in the blood was measured. The concentration in the blood of all 
Figure 2. Average working power during $5 \times 6 \mathrm{~s}$ repeated effort test $\left(\mathrm{W} \cdot \mathrm{kg}^{-1}\right)$ and fatique index FI $(\%)$

Note. A - elite basketball players, $\mathrm{B}$ - young basketball players, $\mathrm{C}$ elite ice hockey players (Ellis et al., 2000).

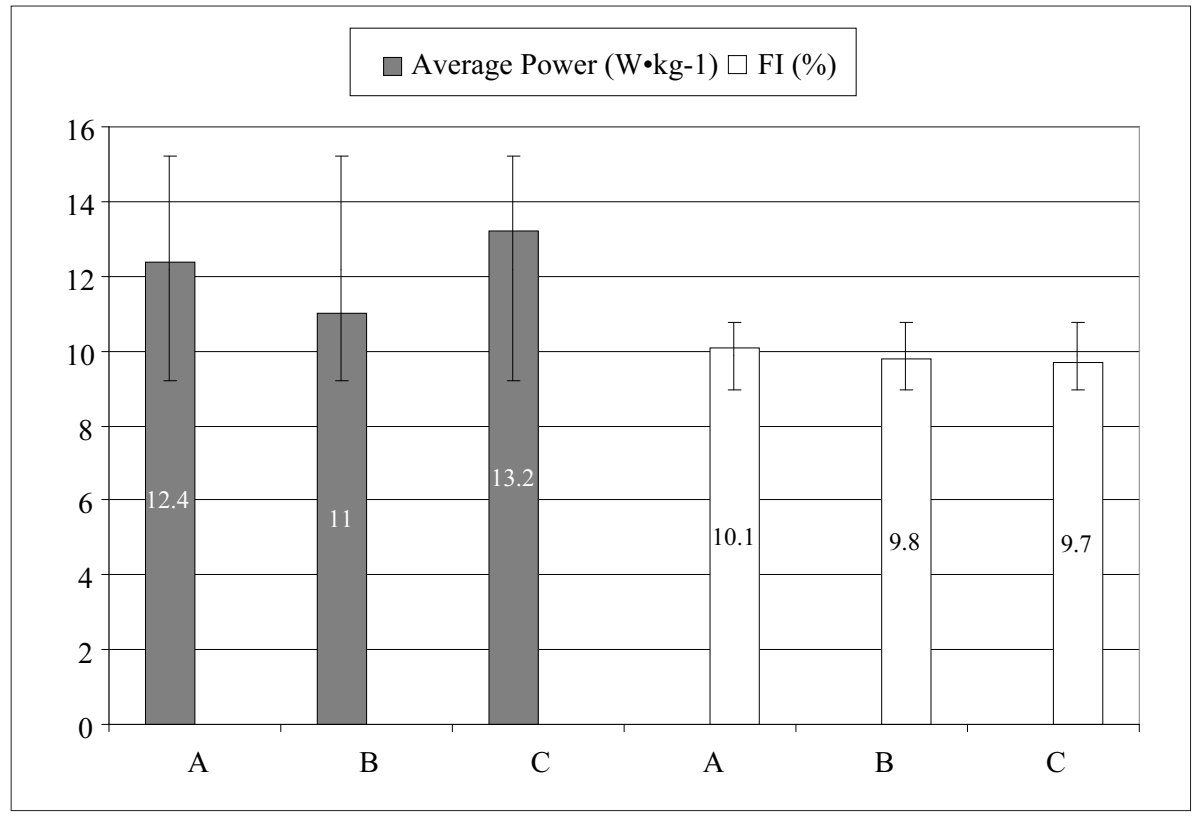

the basketball players considerably exceeded lactate accumulation threshold (LAT) and was the same in both groups. This shows that the amount of PCr, which is necessary for ATP resynthesis, starts decreasing during repetitive work and the activity of anaerobic glycolytic reactions increases. However, the dispersion of indicators around the mean show that contribution of energy sources to capacity of repetitive work is very individual.

\section{CONCLUSIONS AND PERSPECTIVES}

1. The research revealed that relative muscle power of elite basketball players did not differ from those of young athletes.

2. The same anaerobic repetitive muscle work capacity was observed in both groups.

3. It was established that the concentration of lactate in the blood increased after physical load and did not differ in the two groups.

\section{REFERENCES}

Astrand, P., Rodahl, K. (1986). Textbook of Work Physiology. New York: McGraw Hill.

Bompa, T. O., Haff, G. (2009). Periodization: Theory and Methodology of Training. Champaign, IL: Human Kinetics.

Buceta, J. M. (2000). Planing basketball activities. The Basketball for Young Players. Madrid: FIBA.

Carter, J. E. L., Ackland, T. R., Kerr, D. A., Stappf, A. B. (2005). Somatotype and size of elite female basketball player. Journal of Sport Sciences, 23, 1057-1063.

Ellis, L., Gastin, P., Lawrence, S. et al. (2000). Protocols for the physiological assessment of team sport players. In Ch. J. Gore (Ed. ), Physiological Tests for Elite Athletes. Australian sport commission (pp. 128-144). Champaign, IL: Human Kinetics.

Fitszimons, M., Dawson, B., Ward D., Wilkinson, A. (1993). Cycling and running tests of repeated sprint ability. Australian Journal of Science and Medicine in Sport, 25, 82-87.
Foster C., Brackenbury, C., Moore, M., Snyder, A. (1996). System of sports specific performance diagnosis and monitoring of training in endurance sports and ball games in the United States. Deutche Zeitscrift fur Sportmedizin, 45, 190-195.

Hargreaves, M., Meredith, I., Jennings, G. L. (1992). Muscle glycogen and glucose uptake during exercise in humans. Experimental Physiology, 77, 641-644.

Karipidis, A., Fotinakis, P., Taxildaris, K., Fatouros, J. (2001). Factors charcterising a successful performance in basketball. Journal of Human Movement Studies, 41, 385-397.

Kraemer, W. H., Ratamess, N. A. (2005). Hormonal responses and adaptations to resistance exercise and training. Sports Medicine, 35, 339-361.

Kraemer, W. J. (2000). Physiological adaptation to anaerobic and aerobic endurance training programs. In T. R. Baechle (Ed.), Essentials of Strengths Training and Conditioning $\left(2^{\text {nd }}\right.$ ed.). Champaign, IL: Human Kinetics. 
Krause, J. V., Meyer, D., Meyer, J. (2008). Basketball Skills and Drills. (3 ${ }^{\text {rd }}$ ed.). Champaign, IL: Human Kinetics.

Mendes, L., Janeira, M. (2001). Basketball performancemultivariate study in Portuguese professional male basketball teams. In Proceedings of Notational Analysis of Sport IV (pp. 103-111). Cardiff: UWIC.

Paulauskas, R., Skernevičius, J., Paulauskienè, R. (2010). The anaerobic muscle capacity of high level female basketball players and its evaluation scales. In J. Grants (Ed.), Proceedings of Physical Activity and Sport in Changing society: Research, Theory, Practice and Management (pp. 101-102). Riga, Latvia: Latvian Academy of Sport Education.

Stapff, A. (2000). Protocols for the physiological assessment of basketball players. In Ch. J. Gore (Ed.),
Physiological Tests for Elite Athletes (pp. 224-238). Champaign, IL: Human Kinetics.

Trninic, S., Dizdar, D., Dezman, B. (2000). Empirical verification of the weighted system of criteria for the elite basketball players quality evaluation. Collegium Antropologicum, 24, 443-465.

Ward, D. (1991). Laboratory test of repeated effort ability and its relation to aerobic power, anaerobic power and anaerobic capacity. In Ch. J. Gore (Ed.), Physiological Tests for Elite Athletes (pp. 137-138). Champaign, IL: Human Kinetics.

Wilmore, J., Costill, D., Kenney, W. (2008). Physiology of Sport and Exercise. Champaign, IL: Human Kinetics.

Wissel, H. (2004). Basketball: Steps to Success. Champaign, IL: Human Kinetics.

\title{
DIDELIO MEISTRIŠKUMO IR JAUNŲJŲ KREPŠININKŲ ANAEROBINIS RAUMENU PAJĖGUMAS IR KARTOTINIO DARBO IŠTVERMÉ
}

\author{
Rūtenis Paulauskas, Rūta Dadelienė, Rasa Paulauskienė, Juozas Skernevičius \\ Lietuvos edukologijos universitetas, Vilnius, Lietuva
}

\section{SANTRAUKA}

Tyrimo pagrindimas ir hipotezè. Žaidejai darbo metu turi atlikti labai intensyvų kartotini darbą ir trumpu pertraukèlių metu greitai atsigauti. Manoma, kad didelio meistriškumo krepšininkų anaerobinis darbo galingumas ir kartotinio darbo ištvermė yra didesni nei jaunujų krepšininkų.

Tikslas - nustatyti didelio meistriškumo $(\mathrm{n}=13)$ ir jaunų žaidèjų $(\mathrm{n}=12)$ anaerobini pajègumą ir kartotinio darbo ištvermę bei atlikti lyginamają analizę.

Metodai. Varžybų laikotarpiu buvo atliktas $5 \times 6$ sekundžių kartotinio darbo testas darant 24 s poilsio pertraukas. Buvo paskaičiuotas kiekvieno darbo intervalo vidutinis galingumo rodiklis bei nustatytas nuovargio indeksas. Po fizinio krūvio praejus trims minutems, buvo nustatyta laktato koncentracija kraujyje.

Rezultatai. Absoliutaus raumenų pajègumo rodikliai didelio meistriškumo žaidèjų buvo statistiškai reikšmingai didesni visų darbo intervalų metu. Tačiau santykiniai darbo galingumo rodikliai, išreikšti vienam kilogramui kūno masės, statistiškai nesiskyrè. Pirmuoju darbo intervalu didelio meistriškumo žaidèjų jis buvo $13,06 \mathrm{~W} \cdot \mathrm{kg}^{-1}$, jaunuju krepšininkų - 11,74 W· $\mathrm{kg}^{-1}$ (skirtumas $\mathrm{p}<0,09$ ). Nuovargio indekso rodikliai abiejų grupių tiriamujų nesiskyré $(\mathrm{p}<0,77)$, statistinio skirtumo tarp laktato koncentracijos rodiklių taip pat nebuvo $(\mathrm{p}<0,778)$.

Aptarimas ir išvados. Nors absoliutūs raumenu pajègumo rodikliai didelio meistriškumo žaidèjų ir buvo didesni, žaidžiant krepšinị svarbūs santykiniai rodikliai (kur reikalinga įveikti kūno masės pasipriešinimą) statistiškai patikimai nesiskyrè. Po krūvio abiejų grupių laktato koncentracija viršijo $9 \mathrm{mmol} \cdot \mathrm{l}^{-1}$. Vadinasi, dirbant 5 kartus po 6 sekundes ir 4 kartus ilgiau ilsintis KF atsargu ATP resintezei nepakanka, todèl yra aktyvuojamos anaerobinės glikolitinès reakcijos.

Raktažodžiai: nuovargis, laktatas, atsigavimas, raumenys.

Gauta 2012 m. balandžio 25 d.

Received on April 25, 2012

Priimta $2012 \mathrm{~m}$. birželio $8 \mathrm{~d}$.

Accepted on June 8, 2012

Corresponding author Rūtenis Paulauskas

Lithuanian University of Educational Sciences Studentų str. 39, LT-08106 Vilnius

Lithuania

Tel +370 52734858

E-mail rutenis.paulauskas@vpu.lt 